\title{
ANALYSIS OF CYANOBACTERIAL DIVERSITY OF SOME HOT SPRINGS IN AFYONKARAHISAR, TURKEY
}

\author{
YILMAZ CANKILIC, M. $^{1 *}-$ ARIK BERK, G. ${ }^{1}$ \\ ${ }^{1}$ Anadolu University, Faculty of Sciences, Department of Biology, Eskisehir/TURKEY \\ (phone: 090-335-05-80/4713; fax: 090-320-49-10) \\ *corresponding author: \\ e-mail:meralyilmaz@anadolu.edu.tr \\ (Received $13^{\text {th }}$ Oct 2015; accepted $5^{\text {th }}$ Mar 2016)
}

\begin{abstract}
The cyanobacterial diversity of Ömerli, Akkuş-Gazlıg̈l, and Hüdai-Sandıklı hot springs in Afyonkarahisar District in Turkey were analysed and compared using cultivation and cultivationindependent methods, including DGGE (denaturing gradient gel electrophoresis) and cloning of PCRamplified fragments of 16S rRNA genes. Cultivation studies revealed that a total of 74 isolates had 6 different ARDRA (Amplified Ribosomal DNA Restriction Analysis) profiles and they were identified at the genus level and all cyanobacterial isolates were phylogenetically related to Fischerella, Geitlerinema/Leptolyngbya laminosa and uncultured cyanobacterium genus. A total of 97 clones from 16S rRNA gene library was analysed by ARDRA. 16S rRNA sequence analysis of these clones revealed that the cyanobacterial clones were related to $16 \mathrm{~S}$ rRNA gene sequences retrieved from environmental samples, Geitlerinema and Leptolyngbya laminosa genus members. DGGE analysis revealed Geitlerinema, Cyanobacterium, and Phormidium genus, and 16S rRNA gene sequences retrieved from environmental samples. High-throughput 16S rRNA gene sequencing with DGGE analysis showed that the most frequent sequences in Ömerli, Akkuş-Gazlıgöl and Hüdai-Sandıklı samples were affiliated with Geitlerinema. This work highlights the cyanobacterial diversity of Afyonkarahisar hot springs.
\end{abstract}

Keywords: thermophilic cyanobacteria, hot spring, Afyonkarahisar, cloning, DGGE (Denaturating Gradient Gel Electrophoresis)

\section{Introduction}

Cyanobacteria are Gram-negative bacteria which have the ability of oxygenic photosynthesis. They are the most adaptive photosynthetic organisms and live in almost every habitat on earth. They are found in fresh water, marine water, soil in thermophilic and psychrophilic conditions. Cyanobacterial morphology varies from unicellular to multicellular. Cyanobacteria that can develop over $45^{\circ} \mathrm{C}$ are called thermophilic cyanobacteria. These cyanobacteria have a more limited distribution area than mesophilic cyanobacteria (Whitton and Potts, 2000). Thermal hot springs are found in different geographical areas with different physical and chemical features which severely limit the survival of photoautotrophic organisms in them. Thermal environments make the cyanobacteria living there endemic (Castenholz, 1996; Papke et al., 2003; McGregor and Rasmussen, 2008).

Thus, except a few cosmopolitan thermophilic cyanobacterial species (i.e. Mastigocladus laminosus Cohn) (Castenholz, 1996; Miller et al., 2007), most thermophilic cyanobacteria are new operational taxonomic units (OTUs) (Ward et al., 1998; Taton et al., 2006; McGregor and Rasmussen, 2008).

Cyanobacteria are the most commonly reported microbial groups constituting thermophilic mats and considered as the major primary producers in these habitats (Castenholtz, 1973). Other bacteria living in the same environment have also important 
roles within these microbial communities (Ward et al., 1990; Weller et al., 1992; Moyer et al., 1995).

Afyonkarahisar is a district in western Turkey (Figure 1) with well known hot springs. Although several hot springs in different regions of Afyonkarahisar have been in use for many years, their cyanobacterial diversity has not yet been investigated by molecular phylogenetic approaches.

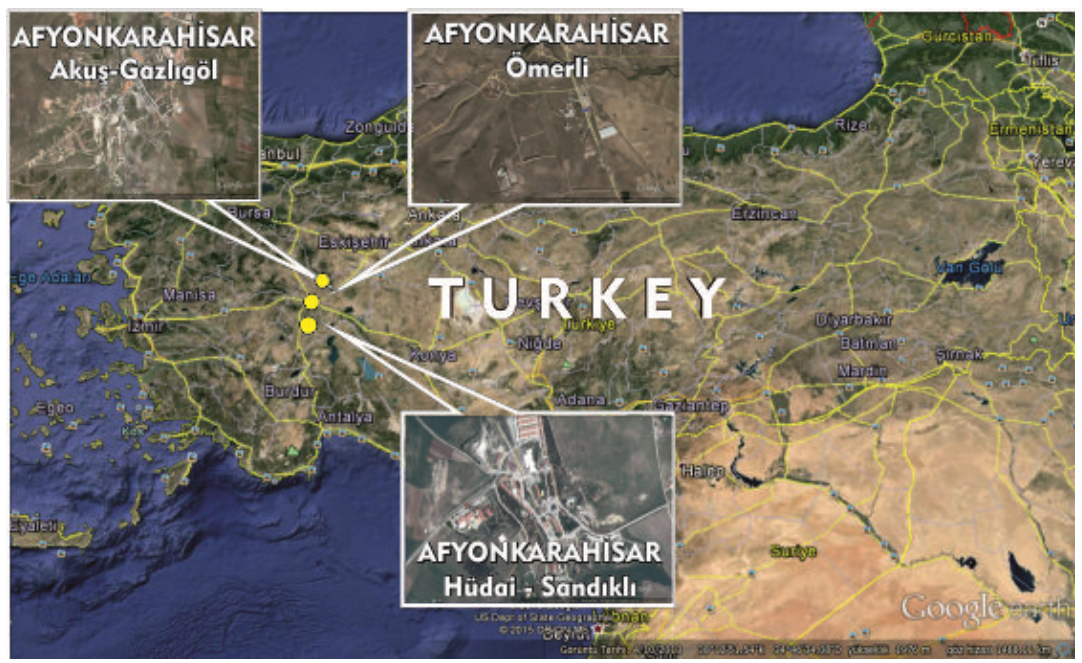

Figure 1. Sampling locations in Afyonkarahisar (shown with circles on the map). GPS coordinates of the sampling points are $38^{\circ} 56^{\prime} 09.43 N-30^{\circ} 29^{\prime} 48.11 \mathrm{E}$ (Akkus-Gazligöl); $38^{\circ} 25^{\prime} 59.26 \mathrm{~N}-30^{\circ} 10^{\prime} 54.89 \mathrm{E}$ (Hüdai-Sandikli); 38 $50^{\circ} 24.45 \mathrm{~N}-30^{\circ} 25^{\prime} 01.08 \mathrm{E}$ (Ömerli). (Satellite imagery: Google/Google Earth).

In this study, we applied the 16S rRNA gene analysis both for isolates and environmental DNA to determine the cyanobacterial community structure of three most popular hot springs in Afyonkarahisar.

\section{Materials and Methods}

\section{Study site and sample collection}

Three hot springs Ömerli $\left(98^{\circ} \mathrm{C}\right)$, Akkuş-Gazlıgöl $\left(64^{\circ} \mathrm{C}\right)$, and Hüdai-Sandıklı $\left(68^{\circ} \mathrm{C}\right)$ in Afyonkarahisar were selected as our study sites (Figure 2).

Water and mat samples were collected as study material. Water samples were taken from the epilimnion at a depth of $1 \mathrm{~m}$ using sterile glass bottles and tubes during January and October 2012 and were kept on ice baths until they were analysed. Microscopic analyses of water samples were performed with Olympos microscope BX51 equipped with digital microphoto-camera DP70. Morphological analyses were carried out at the genus level based on the identification systems proposed by Geitler, 1932 and the "form-genus" approach of Castenholz, 2001. The samples were cultivated with or without nitrogen in BG-11 medium (Rippka et al., 1981; Boutte et al., 2005; Cuzman et al., 2010) supplemented with $50 \mathrm{mg} \mathrm{l}^{-1}$ of cycloheximide to avoid eukaryotic cells. Cultures were grown at $55^{\circ} \mathrm{C}$ for several weeks until a green active biomass became visible and purification process was then performed. Subsequent cultures were incubated in the BG11 solid medium at $55^{\circ} \mathrm{C}$. 


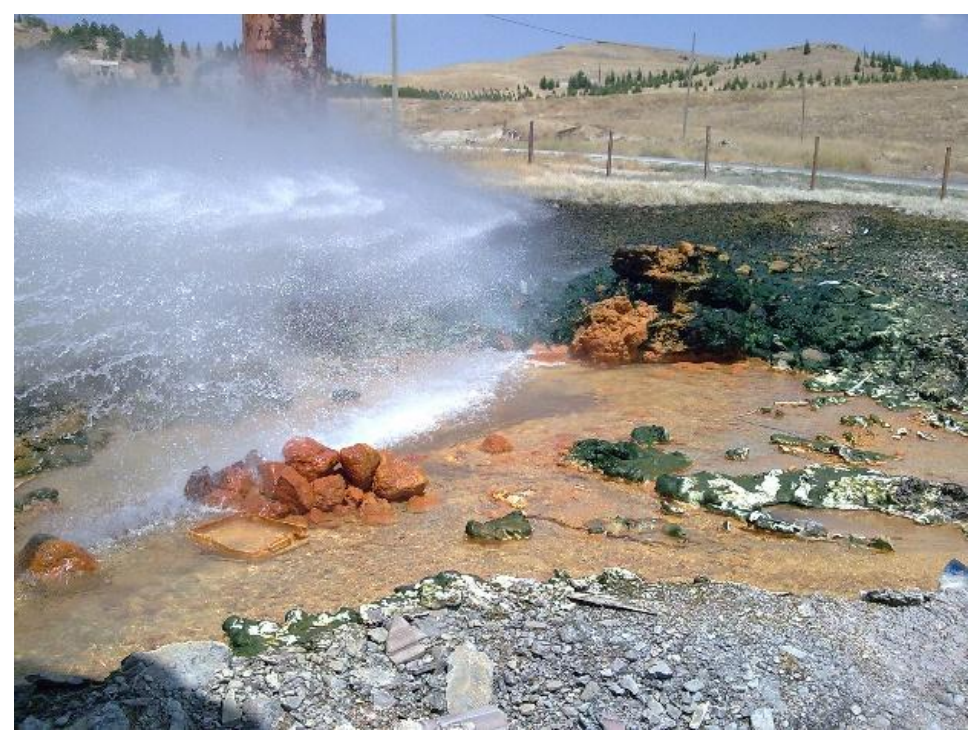

(a)

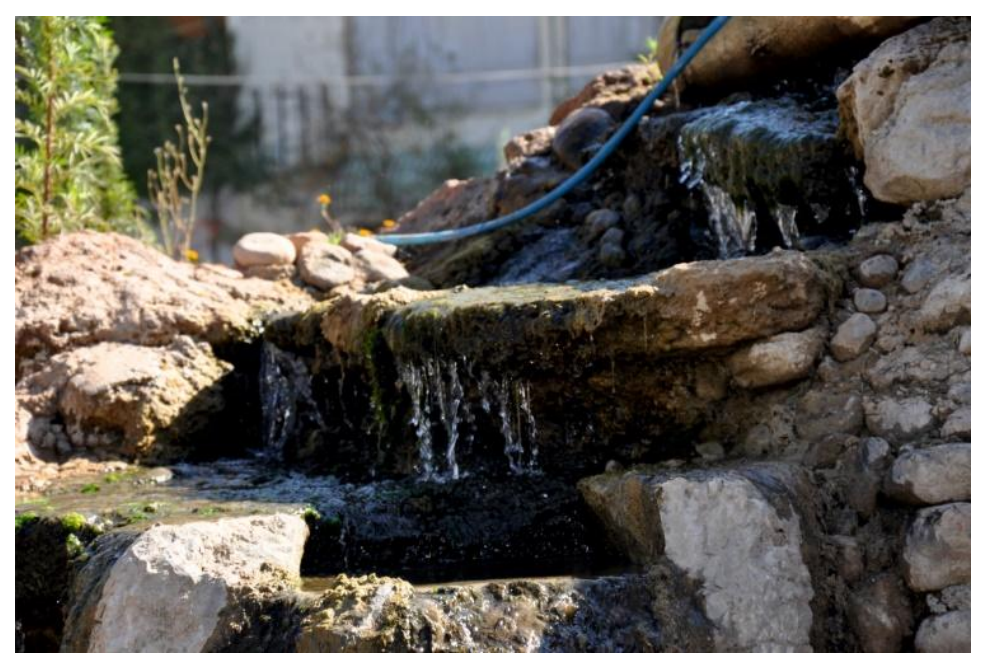

(b)

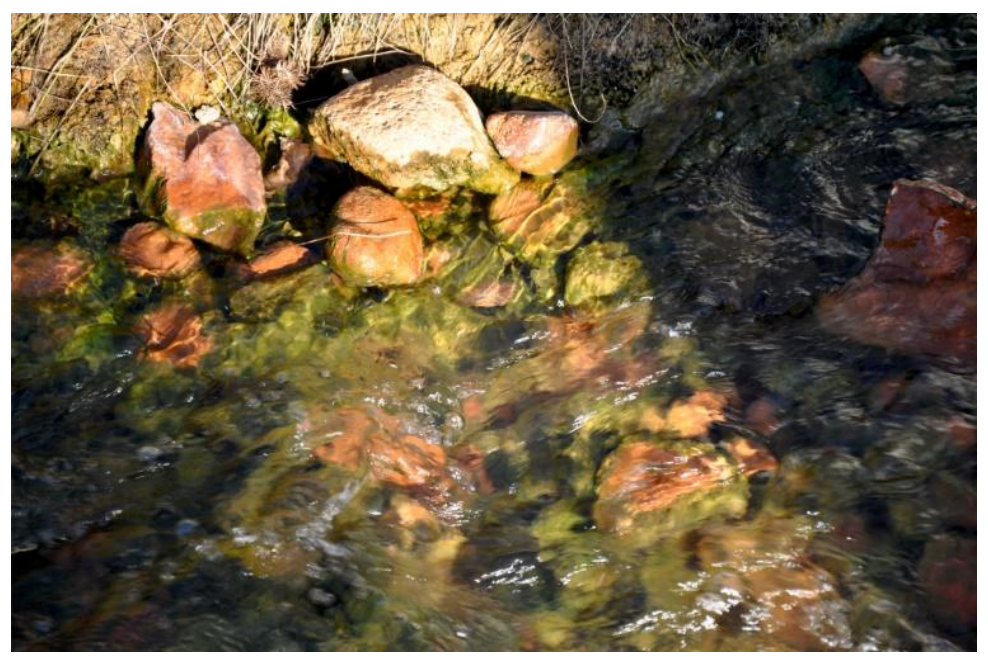

(c)

Figure 2. (a) Ömerli (b) Akkuş-Gazlıgöl (c) Hüdai-Sandıklı hot springs 


\section{Chemical analysis of water samples}

Chemical analysis of all of the water samples from the hot springs (Table 1) was performed with the Spectroquant ${ }^{\circledR}$ NOVA 60 photometer using Merc cell tests.

\section{DNA extraction from pure cultures, mat and water samples}

The bacterial genomic DNAs from purified cultures were prepared using the protocol described by DNeasy ${ }^{\circledR}$ Plant Mini Kit (Qiagen). $500 \mathrm{ml}$ water samples were filtered on $0.2 \mu \mathrm{m}$-pore-size filters (Millipore) to obtain the total bacterial genomic DNA. The filters and mat samples $(0.5 \mathrm{~g})$ with yellow, green and darkgreen layers were obtained from 3-5 mm below the mat surface using a clean razor blade and placed in $15 \mathrm{ml}$ sterile tubes containing $2 \mathrm{ml}$ lysis buffer (40 mM EDTA, $400 \mathrm{mM} \mathrm{NaCl}, 0.75 \mathrm{M}$ sucrose, $50 \mathrm{mM}$ Tris $\mathrm{HCl} \mathrm{pH} \mathrm{8.3).} \mathrm{Each} \mathrm{sample} \mathrm{was} \mathrm{frozen} \mathrm{at}$ $-20^{\circ} \mathrm{C}$ (Giovannoni et al., 1990). For the enzymatic lysis step, a volume of $50 \mu \mathrm{l}$ lyzozyme $(50 \mathrm{mg} / \mathrm{ml})$ was added to the filters and incubated for 20 minutes at $37^{\circ} \mathrm{C}$. After then $100 \mu \mathrm{l}$ SDS $(10 \%)$ and $43 \mu \mathrm{l}$ proteinase $\mathrm{K}(14 \mathrm{mg} / \mathrm{ml})$ was added and incubated 2 hours at $37^{\circ} \mathrm{C} .2 \mathrm{ml}$ of phenol/chloroform/isoamylalcohol (Merck, Germany) (25:24:1) were added and incubated for 10 minutes at $56^{\circ} \mathrm{C}$. The nucleic acids were precipitated from the supernatant (divided in Eppendorf tubes) by adding 2 volumes of ethanol and kept for 2 hours at $-20^{\circ} \mathrm{C}$. Then, the tubes were centrifuged for 20 minutes at $16000 \mathrm{~g}$. After extraction, DNA was subjected to purification step using the Wizard DNA Clean-Up System (Promega). To check the quality of nucleic acids, they were run in 1\% agarose (LE, FMC Products, Rockland, ME) gel and visualized under UV light after ethidium bromide staining. The purified DNA were stored at $-85^{\circ} \mathrm{C}$ (Wilmotte et al., 2002; Boutte et al., 2005).

\section{Cloning of 16S rDNA and ARDRA (Amplified Ribosomal DNA Restriction Analysis)}

The water samples were used for cloning. PCR amplification of the cyanobacterial 16S rRNA gene plus ITS and 5'end of 23S was made in a $3 \times 50 \mu 1$ reaction mixtures. Set of primers used was CYA 359F (5'-ggggaattttccgcaatggg-3') and 23S30R (5'-cttcgcctctgtgtgcctaggt-3') (Taton et al., 2003).

Applied Biosystems ${ }^{\circledR}$ thermal cycler was used for the amplification reaction contained $1 \mathrm{X}$ of Q5 ${ }^{\circledR}$ Reaction Buffer, $1 \mathrm{mg} \mathrm{ml}^{-1}$ of BSA (bovine serum albumin), $200 \mu \mathrm{M}$ of dNTP mix, $0.5 \mu \mathrm{M}$ of the forward and reverse primers, $1 \mathrm{U} / \mu 1$ of $\mathrm{Q} 5 \AA$ High-Fidelity DNA Polymerase (New England Biolabs, Inc) with proofreading activity in a final volume of $50 \mu \mathrm{l}$. The PCR amplification cycle was 5 min at $94^{\circ} \mathrm{C}$; 10 cycles of $45 \mathrm{~s}$ at $94^{\circ} \mathrm{C}, 45 \mathrm{~s}$ at $57^{\circ} \mathrm{C}$, and $2 \mathrm{~min}$ at $68^{\circ} \mathrm{C} ; 25$ cycles of $45 \mathrm{~s}$ at $92^{\circ} \mathrm{C}$, $45 \mathrm{~s}$ at $54^{\circ} \mathrm{C}$, and $2 \mathrm{~min}$ at $68^{\circ} \mathrm{C}$; and a final elongation step of $7 \mathrm{~min}$ at $68^{\circ} \mathrm{C}$. PCR products were purified with Quantum Prep ${ }^{\circledR}$ PCR Kleen Spin Columns (Bio-Rad). Poly (A) extension was performed using Qiagen ${ }^{\circledR}$ A-Addition Kit according to manufacturer's instructions. Cloning of the PCR products was done with a TOPO ${ }^{\circledR}$ TA Cloning Kit (Invitrogen) according to manufacturer's instructions. White and light blue transformants were purified twice by streaking and then were screened by performing colony PCR with the primer pair CYA359F (5'-ggggaattttccgcaatggg-3') and CYA783R (5'-gactactggggtatctaatcccatt-3'). The amplification conditions were as follows: incubation for $10 \mathrm{~min}$ at $94^{\circ} \mathrm{C} ; 35$ cycles of $1 \mathrm{~min}$ at $94^{\circ} \mathrm{C}, 1 \mathrm{~min}$ at $60^{\circ} \mathrm{C}$, 
$1 \min 68^{\circ} \mathrm{C}$; and a final elongation step of $7 \mathrm{~min}$ at $68^{\circ} \mathrm{C}$ (Wilmotte et al., 2002; Boutte et al., 2005).

Plasmid DNAs were extracted with a Quantum Prep Plasmid Miniprep kit (BioRad) by following the manufacturer's instructions. The inserted 16S rRNA gene plus ITS was reamplified with CYA 359F (5'-ggggaattttccgcaatggg-3') and 23S30R (5'cttcgcctctgtgtgcctaggt-3') primers as described above and subjected to ARDRA to screen the clone libraries.

Additionally, the 16S rRNA gene amplicons obtained from the genomic DNA of the culture were used for ARDRA with two different restriction endonucleases, MspI and MboI (MBI Fermentas). The preperation of the digestion reactions were as follows: add $10 \mu \mathrm{l}$ of PCR product to $2 \mu \mathrm{l}$ of $10 \mathrm{x}$ reaction buffer (buffer $\mathrm{R}+-\mathrm{MboI}$, and $\mathrm{Y}+/$ Tango $-\mathrm{MspI}$ ) and $0.5 \mu \mathrm{l}$ of restriction enzyme and complete to final volume of $20 \mu \mathrm{l}$ with water. Incubation was carried out for $3 \mathrm{~h}$ in the water bath at the optimal temperature of $37^{\circ} \mathrm{C}$ (according to company's instruction). The reaction was stopped by incubating at $65^{\circ} \mathrm{C}$ for 25 minutes. Electrophoresis was performed at constant $90 \mathrm{~V} / \mathrm{cm}$ for 180 minutes. The gel was stained with ethidium bromide after the migration and just visualized with UV light. pBR322 DNA/Alu I Marker (MBI Fermentas) was used as a marker (Boutte et al., 2005). The ARDRA patterns were compared according to the band positions, and identical patterns were considered as the same group. Partial sequences of $16 \mathrm{~S}$ rDNAs from representatives of each group were determined. For each ARDRA type, sequencing was made with primers 23S30R (5'-CTTCGCCTCTGTGTGCCTAGGT-3'), 1492R (5'-GTA CGG CTA CCT TGT TAC GAC-3'), and 1092R (GCG CTC GTT GCG GGA CTT) by Macrogen (Seoul, Korea) and then these sequences were assembled.

\section{DGGE Analysis}

Three filter samples and three mat samples from the hot springs were used for the DGGE. A semi-nested PCR was performed so as to increase the sensitivity and to facilitate of the DGGE analysis.

For the first PCR, the forward primer $16 \mathrm{~S} 359 \mathrm{~F}$ (5'-GGG GAA TTT TCC GCA ATG GG-3') and the reverse primer 23S30R (5'-CTT CGC CTC TGT GTG CCT AGG T-3') were used. $0.5 \mu 1$ of the DNA was added to $49.5 \mu 1$ of the amplification mixture, where the final concentrations of the components were $1 \mathrm{X}$ of $\mathrm{Q} 5{ }^{\circledR}$ Reaction Buffer, $1 \mathrm{mg} \mathrm{ml}^{-1}$ of BSA (bovine serum albumin), $200 \mu \mathrm{M}$ of dNTP mix, $0.5 \mu \mathrm{M}$ of the forward and reverse primers, $1 \mathrm{U} / \mu 1$ of $\mathrm{Q} 5{ }^{\circledR}$ High-Fidelity DNA Polymerase (New England Biolabs, Inc) with proofreading activity in a final volume of $50 \mu$ l. The amplification procedure was as follows: one cycle of $5 \mathrm{~min}$ at $94^{\circ} \mathrm{C}$; Touch down 10 cycles of $\left(6\right.$ cycles of $45 \mathrm{~s}$ at $94^{\circ} \mathrm{C}, 1 \mathrm{~min} 60^{\circ} \mathrm{C}, 1.5 \mathrm{~min}$ at $68^{\circ} \mathrm{C} ; 4$ cycles of $45 \mathrm{~s}$ at $94^{\circ} \mathrm{C}, 1 \mathrm{~min} 60^{\circ} \mathrm{C}, 1.5 \mathrm{~min}$ at $68^{\circ} \mathrm{C}$ ) and the final elongation step was done for $7 \mathrm{~min}$ at $68^{\circ} \mathrm{C}$ for the b1 reaction. For the al reaction, $5 \mathrm{~min}$ at $94^{\circ} \mathrm{C}$, 27 cycles of $45 \mathrm{~s}$ at $94^{\circ} \mathrm{C}, 1 \mathrm{~min}$ at $54^{\circ} \mathrm{C}$, and $1.5 \mathrm{~min}$ at $68^{\circ} \mathrm{C}$ and final elongation step was done for $7 \mathrm{~min}$ at $68^{\circ} \mathrm{C}$. The resulting PCR products $(0.5 \mu 1)$ were served as templates for the second PCR, which was performed with the forward primer 16S359F and reverse primers 16S781R (a) (5'-GAC TAC TGG GGT ATC TAA TCC CAT T-3') and 16S781R (b) (5'-GAC TAC AGG GGT ATC TAA TCC CTT T-3'). A 38-nucleotide GC-rich sequence (5'-CGC CCG CCG CGC CCC GCG CCC GTC CCG CCG CCC CCG CC-3') was attached to the 5' end of each of the reverse primers (Nübel et al., 1997; Boutte et al., 2006). 
The reaction conditions were the same as those described above except the amplification process which involved incubation for $5 \mathrm{~min}$ at $94^{\circ} \mathrm{C}$, followed by 35 cycles (b2) $/ 30$ cycles (a2) of $1 \mathrm{~min}$ at $94^{\circ} \mathrm{C}, 1 \mathrm{~min}$ at $60^{\circ} \mathrm{C}$, and $1 \mathrm{~min}$ at $68^{\circ} \mathrm{C}$ and then a final elongation step of $7 \mathrm{~min}$ at $68^{\circ} \mathrm{C}$. Two distinct reactions were performed for each reverse primer. The negative control for the first PCR was used in the second PCR to check for contamination. DGGE was made by Ingeny system and performed as described by Nübel et al., 1997 with the following modifications. The PCR products obtained with primers 16S781R (a) and 16S781R (b) were applied separately to the polyacrylamide gel. The gel contained a linear 40 to $65 \%$ denaturant gradient, the $\mathrm{pH}$ of the TAE buffer was adjusted to 7.4, and the electrophoresis was applied for $22 \mathrm{~h}$ at $80 \mathrm{~V}$ and $60^{\circ} \mathrm{C}$. After being stained with ethidium bromide, the gel was visualized under UV light and then photographed by Uvitec gel documentation system. The DGGE bands were excised with a surgical scalpel. Each small gel block was placed in $100 \mu \mathrm{l}$ of sterile water for $2 \mathrm{~h}$ at room temperature. Each solution was used as a template for PCR amplification as described above. The PCR products were then electrophoresed to confirm the bands. 350-bp part of 16S rRNA gene was sequenced with primer 16S784R (5'-GGA CTA CWG GGG TAT CTA ATC CC-3').

\section{Nucleotide sequence accession numbers}

Environmental 16S rRNA gene sequences from Afyonkarahisar hot springs are available at the GenBank with the accession numbers KJ461812-KJ461849, KT715745-KT715753, and KT793918-KT793927.

\section{Analyses of sequence data}

All sequences were compared to the sequences in the BLAST search program at the National Center for Biotechnology Information website (http://www.ncbi.nlm.nih.gov). 16S rRNA sequences of the hits for our sequences were obtained through the RDP (Ribosomal Database Project) site at Michigan State University (http://rdp.cme.msu.edu/). The top five hits as well as some additional relevant sequences were used for phylogenetic analysis. Sequences of partial $16 \mathrm{~S}$ rDNA of cultures, clones and DGGE fragments were analysed by BioEdit v7.2.5 software. All sequences were checked for chimera formation using the DECIPHER (Wright et al., 2012). CHECK-CHIMERA software developed by the Ribosomal Database Project and the phylogenetic affiliations of their $5^{\prime}$ and $3^{\prime}$ ends were compared. Phylogenetic trees were constructed using the maximum likelihood treeing algorithm and Nearest-Neighbor-Interchange (NNI) method in the MEGA 6 (Tamura et al., 2007). The Distance Matrix was calculated using the Jukes-Cantor correction. Validity of the tree topology was checked using the bootstrap method (1000 replicates). 


\section{Results}

\section{Chemical properties of the hot spring water samples}

As shown in Table 1, waters of three springs have little difference in their properties.

Table 1. Some properties of the water samples $(\mathrm{mg} / \mathrm{l})$

\begin{tabular}{|c|c|c|c|}
\hline & $\begin{array}{l}\text { Akkuş- } \\
\text { Gazlıgöl } \\
\left(64^{\circ} \mathrm{C}\right)\end{array}$ & $\begin{array}{l}\text { Hüdai- } \\
\text { Sandıklı } \\
\left(68^{\circ} \mathrm{C}\right)\end{array}$ & $\begin{array}{l}\text { Ömerli } \\
\left(98^{\circ} \mathrm{C}\right)\end{array}$ \\
\hline pH & 8.3 & 7.06 & 7.06 \\
\hline $\mathrm{Mg}^{2+}$ & 19.3 & 30 & 20.6 \\
\hline $\mathrm{NO}_{3}{ }^{-}$ & $<0.5$ & $<0.5$ & $<0.5$ \\
\hline $\mathrm{Mn}^{2+}$ & 0.14 & 0.10 & 0.13 \\
\hline $\mathrm{NH}_{4}^{+}$ & $<0.5$ & $<0.5$ & $<0.5$ \\
\hline $\mathbf{P}$ & 0.4 & 0.4 & 1.7 \\
\hline $\mathbf{N}$ & $<0.5$ & $<0.5$ & 0.0 \\
\hline $\mathrm{Cl}_{2}$ & $\begin{array}{l}0.18 \\
* 0.15\end{array}$ & $\begin{array}{l}0.07 \\
* 0.07\end{array}$ & $\begin{array}{l}0.13 \\
* 0.12\end{array}$ \\
\hline CSB/COD & $<10$ & $<10$ & 14 \\
\hline $\mathrm{NO}_{2}^{-}$ & 0.020 & 0.044 & 0.048 \\
\hline $\mathbf{F}^{-}$ & 1.85 & 1.68 & 1.83 \\
\hline
\end{tabular}

\section{Microscopic observation and cyanobacterial cultivation analysis of the water samples of the springs}

Microscopical examinations of the water samples of the hot springs showed a dominance of filamentous cyanobacteria (Figure 3). The cyanobacteria found were described based on their morphologies. Oscillatoria-like cyanobacteria were dominant and Gleocapsa-like unicellular cyanobacteria were encountered less frequently. 74 pure isolates having 6 different ARDRA profiles (Table 2) were obtained from the hot springs. BLAST analysis of partial $16 \mathrm{~S}$ rDNA obtained from the isolates showed that Ömerli hot spring has more cyanobacterial diversity than the other two. ARDRA profiles of the isolates and their closest Genbank matches are shown in Table 3. 
In our ARDRA results, $73 \%$ of the isolates belong to the group $\mathrm{S} 1$. The groups $\mathrm{S} 2$, S3, S4, S5, and S6 are 4.05\%, 6.75\%, 2.70\%, $12.16 \%$ and $1.35 \%$, respectively. The similarities among the isolates with the closest relative sequences in Gen Bank can be seen in Table 3.

The sequences of the isolates CY2, CY9, and CY16 have similar with the genus Fischerella sp. isolated from Costa Rica (Unpublished, Acc. Number DQ786171). The CY8 isolate sequence showed identity with the Uncultured cyanobacterium obtained from as-rich and DIC-limited geothermal waters of El Tatio, Chile (Unpublished, Acc. Number KP794044.1) and Fischerella sp. (Acc. Number HM636645). The sequences of CY32, CY20, CY11, CY13 and CY31 were similar with the genus Geitlerinema sp./Leptolyngbya laminosa isolated from Euganean thermal muds, Padova, Italy (Unpublished, Acc. Number FM210758).

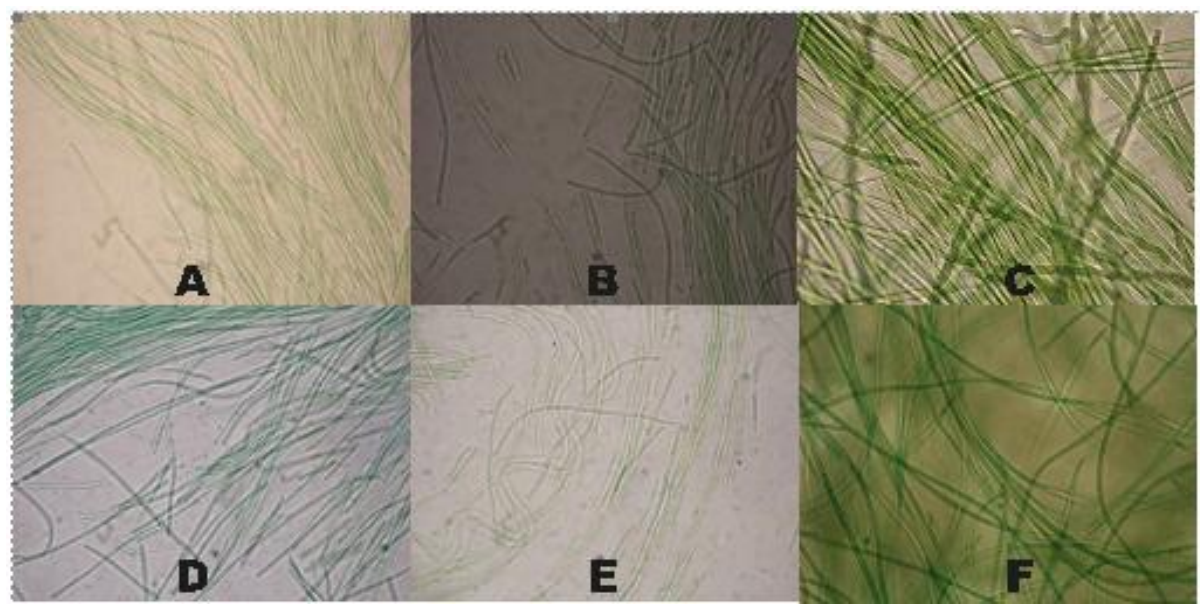

Figure 3. Light microscopy images of some cultures (40X objective). A, B, C, D, E, F trichome morphology of Oscillatoria- like field colonies in BG-11 medium.

Table 2. Isolates, clones and the DGGE bands of Akkuş-Gazlıgöl, Hüdai-Sandiklı and Ömerli hot springs and their ARDRA groups

\begin{tabular}{|c|c|c|c|}
\hline & Isolates & Clone libraries & DGGE bands \\
\hline $\begin{array}{l}\text { Akkuş- } \\
\text { Gazlıgöl }\end{array}$ & $\begin{array}{l}\mathbf{1 4} \text { isolates } \\
\text { Group S1 (9 isolates) } \\
\text { Group S3 (5 isolates) }\end{array}$ & $\begin{array}{l}30 \text { clones } \\
\text { Group K1 (26 clones) } \\
\text { Group K2 (2 clones) } \\
\text { Group K6 ( } 2 \text { clones) }\end{array}$ & $\begin{array}{l}2 \text { DGGE (a2) band } \\
\text { (A.2.1, A.2.2) } \\
7 \text { DGGE (b2) band } \\
\text { (B.2.1, B.2.2, B.2.3, B.2.4, B.2.5, } \\
\text { B.8.1, B.8.2) }\end{array}$ \\
\hline $\begin{array}{l}\text { Hüdai- } \\
\text { Sandıklı }\end{array}$ & $\begin{array}{l}\mathbf{1 7} \text { isolates } \\
\text { Group S1 (15 isolates) } \\
\text { Group S5 (2 isolates) }\end{array}$ & $\begin{array}{l}32 \text { clones } \\
\text { Group K1 (2 clones) } \\
\text { Group K2 (22 clones) } \\
\text { Group K3 (1 clones) } \\
\text { Group K4 ( } 7 \text { clones) }\end{array}$ & $\begin{array}{l}3 \text { DGGE (a2) band } \\
(\text { A.5.3, A.5.4, A.5.5) } \\
2 \text { DGGE (b2) band } \\
(\text { B.6.1, B.6.3) }\end{array}$ \\
\hline
\end{tabular}




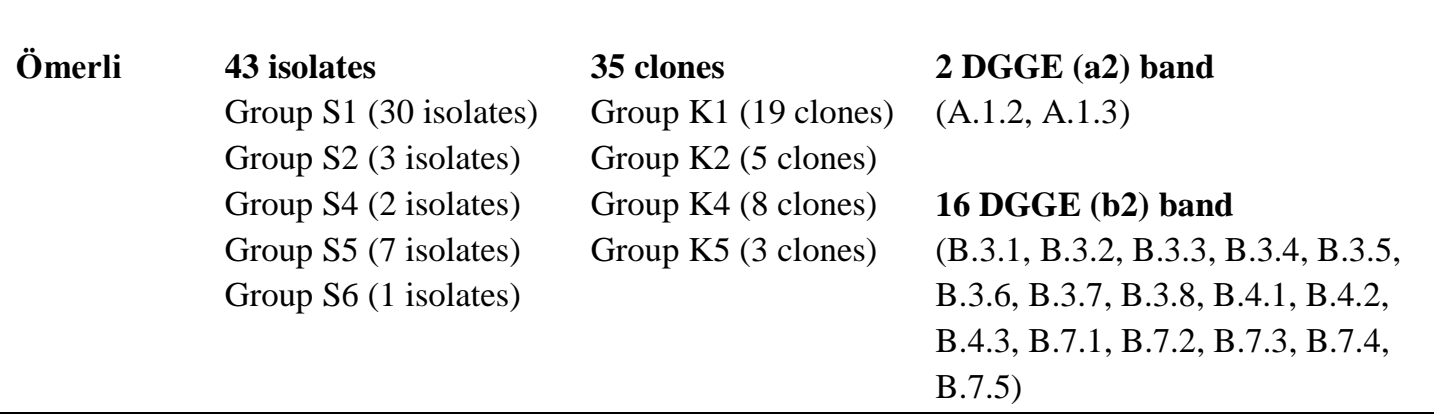

Table 3. Cyanobacterial isolates, clones and their closest GenBank Matches.

\begin{tabular}{|c|c|c|c|c|}
\hline & $\begin{array}{l}\text { ARDRA } \\
\text { Group } \\
\text { No }\end{array}$ & $\begin{array}{l}\text { Sample Code } \\
\text { (Accession } \\
\text { no) }\end{array}$ & $\begin{array}{l}\% \text { of identity } \\
\text { with the closest } \\
\text { relative }\end{array}$ & $\begin{array}{l}\text { Closest relative according to } \\
\text { BLAST search/ Accession no/ Length }\end{array}$ \\
\hline \multirow{9}{*}{$\frac{\mathscr{e}}{\frac{\pi}{\pi}}$} & S1 & $\begin{array}{l}\text { CY11 } \\
(\text { KT715748) }\end{array}$ & $\begin{array}{l}99 \% \\
93 \%\end{array}$ & $\begin{array}{l}\text { Geitlerinema sp. (FM210758) / } 1745 \\
\text { Uncultured cyanobacterium clone MSmat.3.11 } \\
\text { (JQ612141) / } 1745\end{array}$ \\
\hline & S1 & $\begin{array}{l}\text { CY20 } \\
(\text { KT715750) }\end{array}$ & $\begin{array}{l}99 \% \\
93 \%\end{array}$ & $\begin{array}{l}\text { Geitlerinema } \text { sp. (FM210758) / } 1780 \\
\text { Uncultured cyanobacterium clone MSmat.3.11 } \\
\text { (JQ612141)/ } 1780\end{array}$ \\
\hline & $\mathrm{S} 2$ & $\begin{array}{l}\text { CY8 } \\
(\text { KT715753) }\end{array}$ & $\begin{array}{l}99 \% \\
99 \%\end{array}$ & $\begin{array}{l}\text { Uncultured cyanobacterium (KP794044.1) } \\
\text { /1087 } \\
\text { Fischerella sp. }(\text { HM636645) / } 1087\end{array}$ \\
\hline & S3 & $\begin{array}{l}\text { CY32 } \\
\text { (KT715752) }\end{array}$ & $\begin{array}{l}99 \% \\
99 \%\end{array}$ & $\begin{array}{l}\text { Geitlerinema sp. (FM210758) /1089 } \\
\text { Uncultured Leptolyngbya sp. } \\
\text { Tsenher12otu4-1 (KT258783) / } 1089\end{array}$ \\
\hline & S3 & $\begin{array}{l}\text { CY31 } \\
(\text { KT715751) }\end{array}$ & $\begin{array}{l}96 \% \\
96 \%\end{array}$ & $\begin{array}{l}\text { Geitlerinema sp.(FM210758)/1526 } \\
\text { Uncultured Leptolyngbya sp. clone } \\
\text { Tsenher12otu4-1 (KT258783) / 1526 }\end{array}$ \\
\hline & S4 & $\begin{array}{l}\text { CY9 } \\
\text { (KT715746) }\end{array}$ & $\begin{array}{l}99 \% \\
99 \%\end{array}$ & $\begin{array}{l}\text { Fischerella sp. (DQ786171) /1483 } \\
\text { Uncultured bacterium clone B95 (AF407731) / } \\
1483\end{array}$ \\
\hline & S4 & $\begin{array}{l}\text { CY2 } \\
(\text { KT715745) }\end{array}$ & $\begin{array}{l}99 \% \\
99 \%\end{array}$ & $\begin{array}{l}\text { Fischerella sp. (DQ786171) /1491 } \\
\text { Uncultured bacterium clone B95 (AF407731) / } \\
1491\end{array}$ \\
\hline & S5 & $\begin{array}{l}\text { CY13 } \\
\text { (KT715749) }\end{array}$ & $\begin{array}{l}98 \% \\
98 \%\end{array}$ & $\begin{array}{l}\text { Geitlerinema sp. (FM210758) /1531 } \\
\text { Uncultured Leptolyngbya sp. } \\
\text { Tsenher12otu4-1 (KT258783) / 1531 clone }\end{array}$ \\
\hline & S6 & $\begin{array}{l}\text { CY16 } \\
\text { (KT715747) }\end{array}$ & $\begin{array}{l}97 \% \\
97 \%\end{array}$ & $\begin{array}{l}\text { Fischerella sp. (DQ786171) /1428 } \\
\text { Uncultured bacterium clone B95 (AF407731) / }\end{array}$ \\
\hline
\end{tabular}




\begin{tabular}{|c|c|c|c|c|}
\hline & & & & 1428 \\
\hline & K1 & $\begin{array}{l}\text { Clone } 7 \\
\text { (KT793923) }\end{array}$ & $\begin{array}{l}97 \% \\
90 \%\end{array}$ & $\begin{array}{l}\text { Uncultured bacterium (AB757744) /1501 } \\
\text { Cyanothece sp. }(\mathrm{CP} 001344) / 1501\end{array}$ \\
\hline & K1 & $\begin{array}{l}\text { Clone } 21 \\
\text { (KT793924) }\end{array}$ & $\begin{array}{l}99 \% \\
91 \%\end{array}$ & $\begin{array}{l}\text { Uncultured bacterium (AB757744) /1539 } \\
\text { Cyanothece sp. (CP001344) / } 1539\end{array}$ \\
\hline & K2 & $\begin{array}{l}\text { Clone } 15 \\
(\text { KT793921) }\end{array}$ & $\begin{array}{l}99 \% \\
93 \%\end{array}$ & $\begin{array}{l}\text { Geitlerinema } \text { sp. (FM210758)/1737 } \\
\text { Uncultured cyanobacterium clone MSmat.3.11 } \\
\text { (JQ612141)/1737 }\end{array}$ \\
\hline$\stackrel{2}{0}$ & K3 & $\begin{array}{l}\text { Clone } 12 \\
\text { (KT793922) }\end{array}$ & $\begin{array}{l}93 \% \\
93 \%\end{array}$ & $\begin{array}{l}\text { Geitlerinema sp. (FM210758)/1427 } \\
\text { Uncultured Leptolyngbya sp. clone } \\
\text { Tsenher12otu4-1 (KT258783)/ } 1427\end{array}$ \\
\hline & K4 & $\begin{array}{l}\text { Clone } 62 \\
\text { (KT793926) }\end{array}$ & $\begin{array}{l}99 \% \\
91 \%\end{array}$ & $\begin{array}{l}\text { Uncultured bacterium (AB757744) /1470 } \\
\text { Cyanothece sp. (CР001344) / } 1470\end{array}$ \\
\hline & K5 & $\begin{array}{l}\text { Clone } 46 \\
\text { (KT793925) }\end{array}$ & $\begin{array}{l}95 \% \\
88 \%\end{array}$ & $\begin{array}{l}\text { Uncultured bacterium (AB757744)/1623 } \\
\text { Oculatella atacamensis }(\mathrm{KF} 761587) / 1623\end{array}$ \\
\hline & K6 & $\begin{array}{l}\text { Clone } 66 \\
\text { (KT793927) }\end{array}$ & $\begin{array}{l}93 \% \\
91 \%\end{array}$ & $\begin{array}{l}\text { Leptolyngbya laminose (FM210757) / } 1646 \\
\text { Uncultured cyanobacterium clone MSmat.3.11 } \\
\text { (JQ612141)/1646 }\end{array}$ \\
\hline
\end{tabular}

\section{Molecular Analysis}

In addition to cultivation studies, we carried out culture-independent method cloning and Denaturating Gradient Gel Electrophoresis (DGGE) analysis for the determination of the biodiversity of Afyonkarahisar hot springs. To create a clone library containing 16S rRNA + ITS + 5 parts of 23S rRNA inserts, we used cyano-specific PCR primers which are CYA359F and 23S30R pairs. A total of 97 clones containing inserts of the right size were analysed. First, they were classified on the basis of their restriction profiles (Table 2). Akkuş-Gazlıgöl, Hüdai-Sandıkl1, and Ömerli hot springs have 3, 4, and 4 different ARDRA profiles, respectively. These groups are K1, K2, and K6 for Akkuş-Gazlıgöl, K1, K2, K3 and K4 for Hüdai-Sandıkl1, and K1, K2, K4 and K5 for Ömerli hot spring (Table 2). The group K1 clones are the major ones in Akkuş-Gazligöl and Ömerli hot springs. One or two representatives from 6 different restriction groups were sequenced with the sequence primers 1092-1492-23SR. The BLAST analysis of the selected clones is shown in Table 3. $67 \%$ of the cyanobacterial clones were related to Uncultured bacterium $(\geq 95-97 \%$ similarity) / Cyanothece sp. (90-91\% similarity) or Oculatella atacamensis (88\% similarity) as culture. 
The similarities of the clone 7, 21, 62 sequences with Uncultured bacterium obtained from Padang Cermin Hot Spring Water (unpublished, Acc. Number AB757744) as environmental sample and with Cyanothece sp. (unpublished, Acc. Number CP001344) isolated from rice fields in Senegal as isolate were 90\%, 91\%, and 91\%, respectively. Also, the similarities of clone 46 sequence with Uncultured bacterium (Acc. Number AB757744) and Oculatella atacamensis obtained from Atacama Desert (Karina et al., 2014, Acc. Number KF761587) as culture were $95 \%$ and $88 \%$, respectively. The sequence of clone 12 and 15 were $93 \%$ and $99 \%$ identity with the genus Geitlerinema isolated from Euganean thermal muds, Padova, Italy (Unpublished, Acc. Number FM210758). Clone 66 sequence was 93\% similarity with the Leptolyngbya laminosa from Euganean thermal muds, Padova, Italy (Unpublished, Acc. Number FM210757) (Table 3).

For the DGGE fingerprint analyses, we studied the 16S rRNA gene-defined community diversity in cyanobacterial water samples and mats from three hot springs. CYA359F and the CYA781R primer pair were used in DGGE method for the second PCR reaction. 25 and 7 positive bands were identified using DGGE (b2) and (a2), respectively. Representative samples of DGGE separations and some major bands of hot springs cyanobacterial $16 \mathrm{~S}$ rRNA are presented in Figure 4.

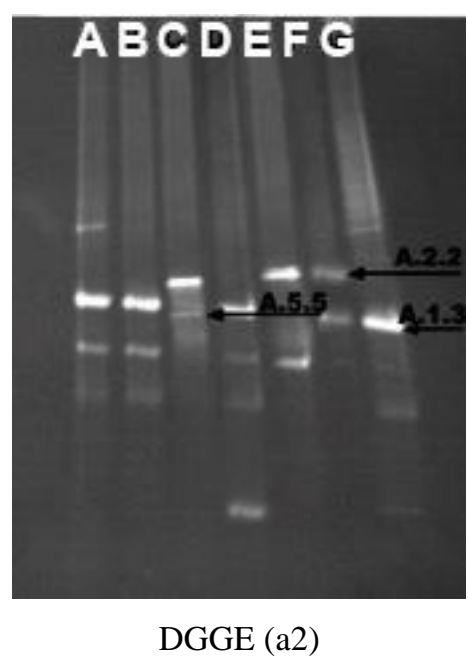

A) Hüdai-Sandıkl water, B) Akkuş-Gazlıgöl mat, C) Hüdai-Sandıkl mat, D)-E) Ömerli mat, F) Akkuş-Gazlıgöl water, G) Ömerli water

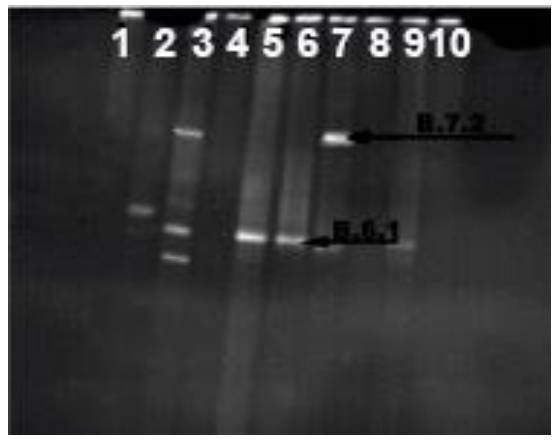

DGGE (b2)

B) (1)-(4) Ömerli water, (2) Akkuş-Gazlıg̈l water, (3)-(7) Ömerli mat, (5)-(6) Hüdai-Sandıklı mat,

C) (8) Akkuş-Gazlıgöl mat, (9) Hüdai-Sandıklı water

Figure 4. DGGE gels (a2) and (b2) of the hot springs and some major bands 
The DGGE band numbers from Akkuş-Gazlıgöl, Hüdai-Sandıklı, and Ömerli hot springs are shown in Table 2. The sequences obtained from most of the the bands $(87.5 \%)$ yielded similarities to Geitlerinema with high percentages of similarity $(99 \% / 100 \%)$ that was isolated from thermal waters in İzmir (Unpublished, Acc. Number HQ197683.1) and one band (B.6.3) was related to the Uncultured bacterium/Cyanobacterium with similarity $99 \% / 100 \%$, respectively that was isolated from Yellowstone National Park, Fairy Springs (Boomer et al., 2009; FJ206395) and Yellowstone National Park, octopus spring cyanobacterial mat (Weller et al., 1992; Acc. Number L04709.1), two bands (A.1.2 and A.1.3) were related to the Uncultured cyanobacterium with similarity 99\% and 94\%, respectively (Unpublished, Acc. Number GQ480617), and one band (A.5.5) was related to the Uncultured cyanobacterium/Phormidium with similarity 99\%/98\% (Unpublished, Acc. Number EU728938.1 and DQ408370.1), respectively (Table 4).

In our DGGE results, Ömerli may have sequences belonging to the Geitlerinema, Uncultured cyanobacterium, Hüdai-Sandıklı may have Geitlerinema, Uncultured bacterium/Cyanobacterium, Uncultured cyanobacterium/Phormidium while AkkuşGazligöl may have only belonging to the Geitlerinema sp. sequences.

Table 4. Obtained DGGE bands and their closest relatives in GenBank

\begin{tabular}{|c|c|}
\hline DGGE bands & $\begin{array}{c}\text { \% Similarity closest relative in BLAST } \\
\text { search of Gen Bank }\end{array}$ \\
\hline $\begin{array}{l}\text { B.2.1, В.2.2, B.2.3, B.2.4, B.2.5, B.3.1, B.3.2, } \\
\text { B.3.3, B.3.4, B.3.5, B.3.6, B.3.7, B.3.8, B.4.1, } \\
\text { B.4.2, B.4.3, B.6.1, B.7.1, B.7.2, B.7.3, B.7.4, } \\
\text { B.7.5, B.8.1, B.8.2, A.2.1, A.2.2, A.5.3, A.5.4 }\end{array}$ & (99-100\%) Geitlerinema sp. (HQ197683.1) \\
\hline B.6.3 & $\begin{array}{l}\text { (100\%) Uncultured bacterium (FJ206395) } \\
\text { (99\%) Cyanobacterium sp. (L04709.1) }\end{array}$ \\
\hline A.1.2, A.1.3 & $\begin{array}{l}(99 \%, 94 \%) \text { Uncultured cyanobacterium } \\
(\mathrm{GQ} 480617)\end{array}$ \\
\hline A.5.5 & $\begin{array}{l}\text { (99\%) Uncultured cyanobacterium (EU728938.1) } \\
\text { (98\%) Phormidium sp. (DQ408370.1) }\end{array}$ \\
\hline
\end{tabular}

\section{Phylogenetic analysis}

Sequences obtained from the isolates, clones and DGGE bands were aligned with the closest strains and retrieved from environmental samples obtained from RDP II and NCBI. Phylogenetic trees for cyanobacteria constructed based on partial 16S rRNA sequences were shown in Figure 5, 6, and 7. Aligned partial 16S rRNA gene sequences corresponding to $E$. coli sequence positions 388 to 1442 for the isolates, 551 to 1525 for the clones and 415 to 717 for the DGGE bands were used but the indels were not taken into account. 


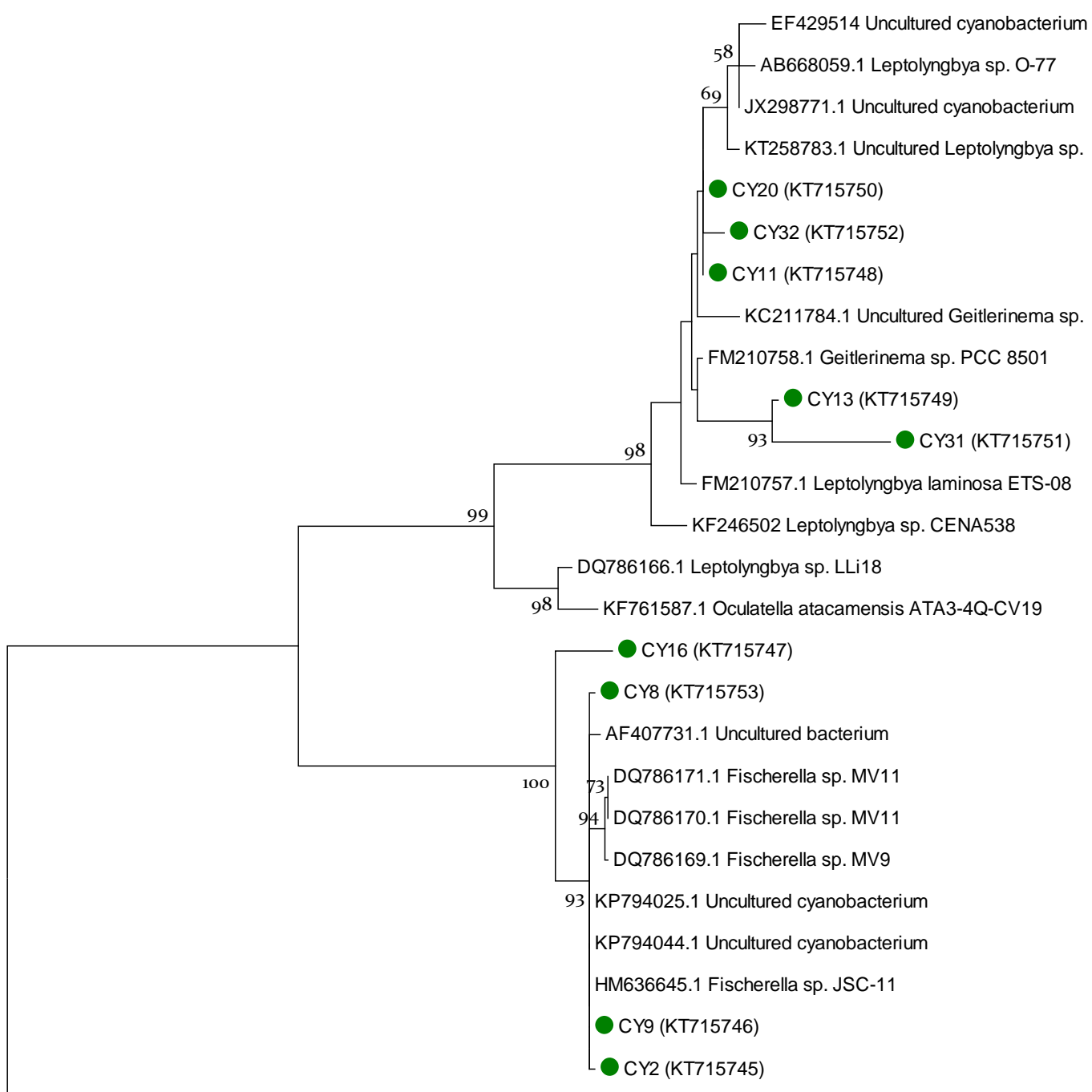

Escherichia coli; ATCC 25922

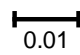

Figure 5. Phylogenetic inferences based on 16S rRNA gene sequences from isolates (indicated by green circle). Sequence of the E.coli was used as outgroup. Scale bar represents expected number of substitutions per site. Bootstrap support values below 50\% were not included in the figure. 


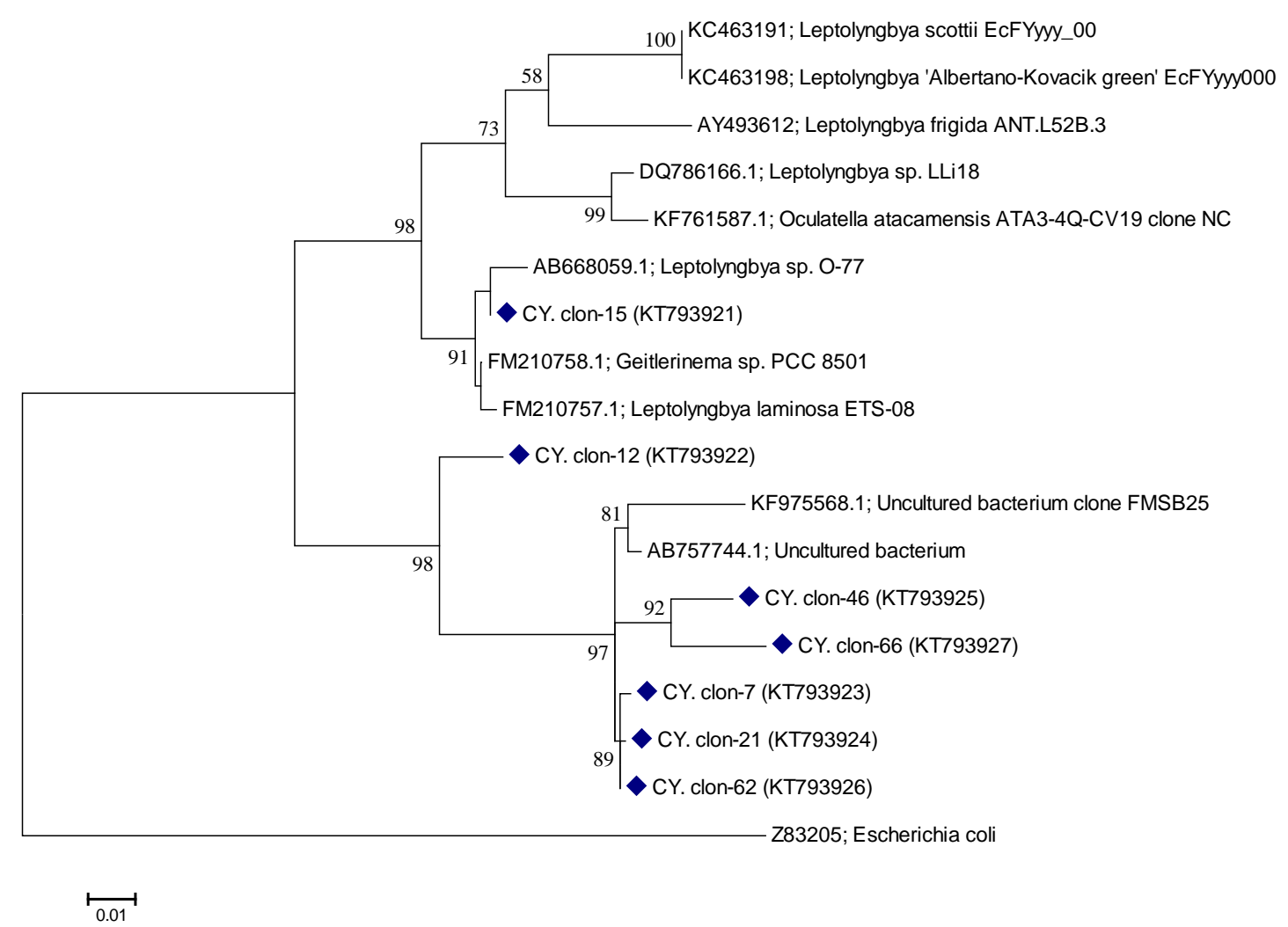

Figure 6. Phylogenetic inferences based on I6S rRNA gene sequences from clones (indicated by blue diamond) belonging to the cyanobacteria. Bootstrap support values below $50 \%$ were not included in the figure. 


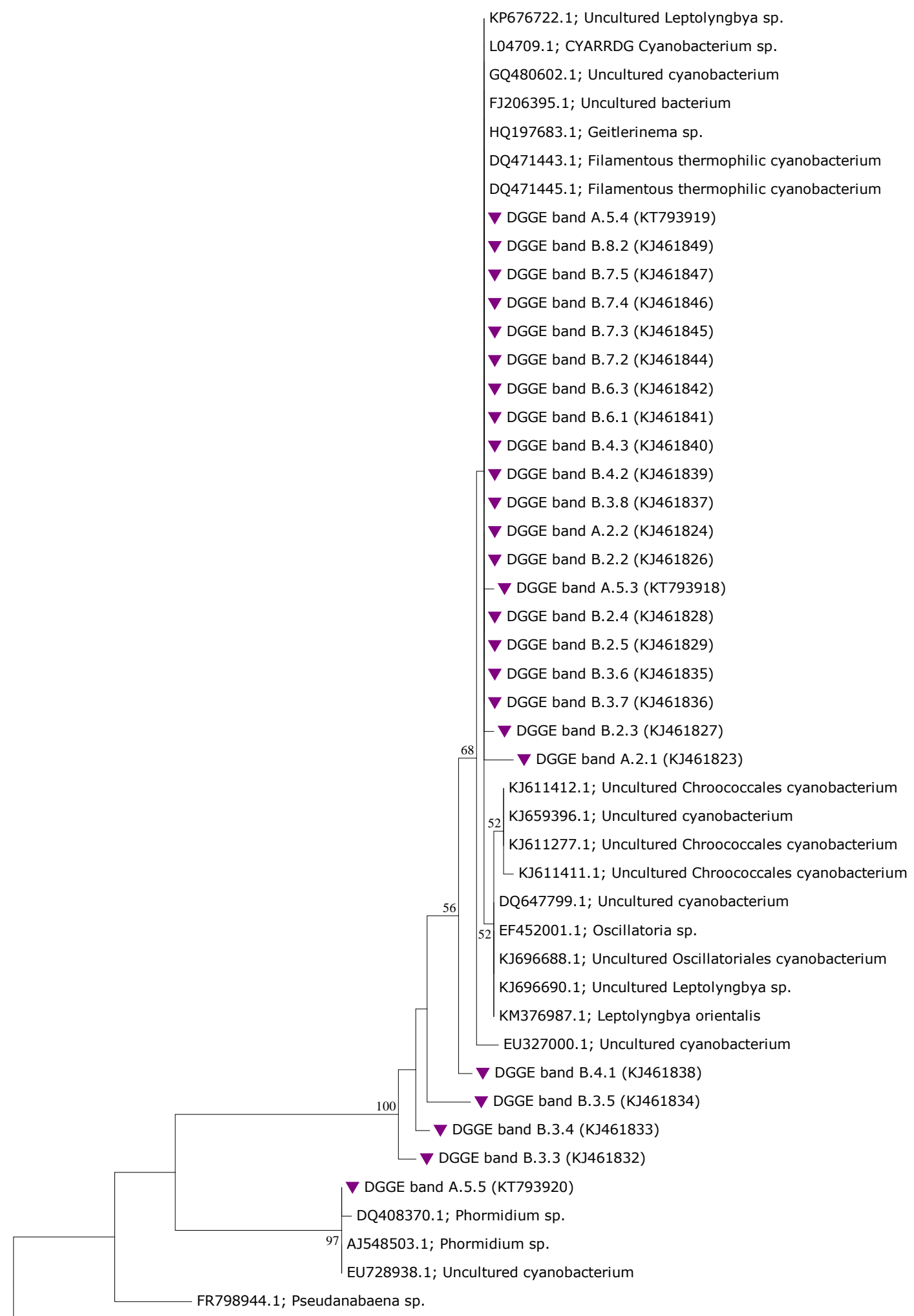

X80724; Escherichia coli; ATCC 25922

$\stackrel{0.01}{0}$

Figure 7. Phylogenetic inferences based on $16 S$ rRNA gene sequences from some DGGE bands (indicated by violet trigon) belonging to the cyanobacteria. Bootstrap support values below $50 \%$ were not included in the figure.

APPLIED ECOLOGY AND ENVIRONMENTAL RESEARCH 14(2): 463-484. http://www.aloki.hu • ISSN 15891623 (Print) • ISSN 17850037 (Online)

DOI: http://dx.doi.org/10.15666/aeer/1402_463484

(c) 2016, ALÖKI Kft., Budapest, Hungary 


\section{Conclusions}

The microbial diversity analysis has shifted in the last two decades from cultivationdependent approaches to 16S rRNA-based cultivation-independent approaches, which led to the discovery of many novel microbial taxa. Nevertheless, this new approach also has limitations and is often restricted $16 \mathrm{~S}$ rRNA clones through sequence similarity. Therefore, cultivation is still the method of choice to understand fully the physiology and complex ecological interactions in which microorganisms engage (Gunde-Cimmerman et al., 2005). The biodiversity of thermophilic cyanobacteria in terrestrial geothermal locations is fairly well documented, where they occur as part of a microbial mat community at temperatures up to $\sim 65^{\circ} \mathrm{C}$, and in biofilms at higher temperatures up to $75^{\circ} \mathrm{C}$ (Ward et al., 1998). The restriction fragment length polymorphisms (RFLPs) of particular PCR products can provide signature profiles specific to the genus, species, or even strain. Genetic characterization of cyanobacterial strains has been undertaken using RFLPs of the 16S rRNA gene (16SARDRA) (Lyra et al., 1997) and of the intergenic transcribed spacer region (ITS-ARDRA) (Lu et al., 1997; West and Adams, 1997).

Furthermore, amplification of the 16S-23S rRNA ITS, whose length and number was shown to be variable in cyanobacteria (West and Adams, 1997; Rocap et al., 2002; Iteman et al., 2002; Neilan, 2002, Laloui et al., 2002; Iteman et al., 2002) in cyanobacteria, can also be used as an identification tool. In this research, we used cultivation and molecular approaches, including DGGE analysis and cloning based on the 16S rRNA gene to reveal the cyanobacterial community composition of three Afyonkarahisar hot springs.

A large number of new thermophilic cyanobacterial isolates have been obtained for a long time by many researchers (Stetter, 1996; Casamatta et al., 2003). Our cyanobacterial isolates and previously cultured cyanobacteria, such as Uncultured cyanobacterium/Fischerella sp and Geitlerinema sp/Leptolyngbya laminosa in Gene-Bank are very similar to each other. The sequence of our isolate CY31 had $96 \%$ similarity with the genus Geitlerinema sp. isolated from Euganean thermal muds, Padova, Italy (Unpublished, Acc. Number FM210758). 16S rRNA sequence similarity (96\%) of CY31 indicates that this strain might be a novel species of the genus. Therefore, further studies, e.g. DNA: DNA homology should be carried out with different Geitlerinema species.

According to the cultivation results, the hot springs of Afyonkarahisar are inhabited by mainly thermophilic filamentous cyanobacteria including the Fischerella sp. and Geitlerinema sp., which are known to exist in thermal springs worldwide (Brock 1978; Ward and Castenholz 2000). Spirulina labyrinthiformis was earlier reported as the dominant organism in material collected by Aaronson from a $52{ }^{\circ} \mathrm{C}$ spring of Zerka Ma'in (Rayss 1944). However, we did not encounter Spirulina sp. in these hot springs. In addition, although one of the best-documented genera of thermophilic cyanobacteria is the genus Synechococcus (Ward et al., 1990, 1998; Miller and Castenholz, 2000; Ramsing et al., 2000; Papke et al., 2003). We did not determine any sequence related this genus in the hot springs.

The diversity and distribution of cyanobacterial groups in the springs were not high. The results obtained from Ömerli, Akkuş-Gazlıgöl and Hüdai-Sandıklı had some similarities with each other and those obtained from the other studies (Reysenbach et al., 1994; Ghosh et al., 2003; Komarek et al., 2003; Hongmei et al., 2005; Sompong et al., 2005; Jing et al., 2006; Sompong et al., 2006; Moro et al., 2007; Ionescu et al., 2009).

Cyanobacterial clones recovered from Ömerli hot spring were phylogenetically related to Uncultured bacterium and Geitlerinema sp. For Hüdai-Sandıklı hot spring, clones were phylogenetically related to Uncultured bacterium and Geitlerinema sp. 
Uncultured bacterium, Geitlerinema sp, and Leptolyngbya laminose sequences were also obtained in Akkuş-Gazligöl hot spring. Although Ömerli has the highest cyanobacterial diversity, Akkuş-Gazlıgöl has more cyanobacterial genus diversity. Contradictory results of same samples were obtained when analyzing the cyanobacterial community inhabiting the hot springs with the culturing. Getilerinema sp. was dominated in the culturing method while Uncultured bacterium/ Cyanothece sp. became major ones with the cloning.

16S rRNA PCR-DGGE is one of the most frequently used technique to assess the genetic diversity of microbial communities (Muyzer, 1999; Ercolini, 2004). This method allows the separation of small DNA fragments (maximum size of $1000 \mathrm{bp}$ ) of the same length but of different sequence according to their melting properties. Fragments with only one single base substitution can be separated with this technique (Nollau and Wagener, 1997). The analysis of these group-specific PCR fragments on a DGGE gel provides a valuable tool for monitoring the structure and dynamics of microbial populations over time or under the influence of environmental changes. Although limitations exist, such as the difficulty on band isolation and too short sequences retrieved to provide a robust phylogenetic analysis, this methodology has been revealed to be a valuable technique to monitor changes in bacterial community structure, both in relative abundance and in bacterial diversity (Lemarchand et al., 2005). We used the specific primers that have the advantage of giving a PCR product which corresponds to the variable regions V3 and V4, and contains significant information for phylogenetic assignments (Nübel et al., 1997; Boutte et al., 2006).

Casamatta et al., 2003 found various cyanobacteria like Pleurocapsa, Phormidium, Anabaena, Synechocystis, Oscillatoria, Microcoleus and Pseudanabaena with 16S rRNA gene sequences along with DGGE inhabiting Octopus hot spring. Similarly, Geitlerinema and Phormidium genus were also detected in our study. Bands that migrated to the same position in the DGGE gel and displayed no ambiguous differences in nucleotide sequences were considered to represent unique $16 \mathrm{~S}$ rRNA sequence types. Moreover, identical sequences were obtained from different bands in the same lane. This is in agreement with the observation of Nikolausz et al., 2005 that dominant amplicons could be distributed at different positions in the same pattern. If several domains have similar melting properties, stochastic effects might cause one to denaturation before the other in a fraction of the amplicon population and could also explain the presence of different bands with the same sequence in one lane.

Consistent with cloning and DGGE, the 16S rRNA gene sequences from Ömerli showed that Geitlerinema sequences were recovered from both method and was dominated with DGGE. Similar to our cultivation results, Geitlerinema sp. was obtained with the cloning and DGGE analysis. But the Fischerella sp. could not be determined with cloning and DGGE sequences.

In this study, although high diversity emerged in ARDRA profile, low diversity in terms of genera was obtained from culture-dependent and culture independent assay results. Previous studies in thermal springs have shown an increasing diversity with decreasing temperature (Kullberg, 1968; Brock, 1978; Castenholz, 1978; Miller and Castenholz, 2000; Sompong et al., 2005). However, this result has some conflicts with ours. According to our results, the cyanobacterial diversity increased with the increasing temperature. Clearly, thermal stress is not a limiting factor since the hottest spring were most biodiverse. The cyanobacteria identified in this study do not follow a single pattern when compared with similar organisms from different thermal sites in the world. Some 
clones and isolates showed low similarities (93-97\%) to those from other environments while others showed over $97 \%$ similarity to their counterparts.

Since thermophiles are notoriously difficult to culture, this study significantly expanded the known range of cultivated thermophilic cyanobacteria and provided a biological resource for future biotechnological exploitation. Furthermore, cultivation and characterization of axenic thermophilic cyanobacterial strains provided a further insight into the physiology of thermophiles and yielded a source of organisms for possible biotechnological exploitation.

It is intriguing that the unique environment of Afyonkarahisar hot springs has not been surveyed for cyanobacterial diversity before. This is the first study in which both culture-dependent and culture-independent techniques have been used simultaneously to target unique regions of the 16S rRNA +ITS gene in samples obtained from Afyonkarahisar hot springs.

Acknowledgments. This work was supported by Anadolu University Research Project No:1002F85 and $1505 \mathrm{~F} 254$.

\section{REFERENCES}

[1] Boomer, S.M., Noll, K.L., Geesey, G.G., Dutton, B.E. (2009): Formation of multilayered photosynthetic biofilms in an alkaline thermal spring in Yellowstone National Park, Wyoming. - Appl Environ Microbiol 75: 2464-2475.

[2] Boutte, C., Grubisic, S., Balthasart, P., Wilmotte, A. (2006): Testing of primers for the study of cyanobacterial molecular diversity by DGGE. - Journal of Microbiological Methods 65: 542-550.

[3] Boutte, C., Komárková, J., Grubisic, S., Znachor, P., Arnaud, B., Eliška, Z., Gullukaya, A., Jezberová, J., Wilmotte, A. (2005): A polyphasic approach to assess the cyanobacterial diversity of summer samples from Czech reservoirs. - Algol Stud 117: 177-195.

[4] Brock, T.D. (1978): Thermophilic Microorganisms and Life at High Temperatures. Springer-Verlag, Berlin.

[5] Casamatta, D.A, Vis, M.L, Sheath, R.G. (2003): Cryptic species in cyanobacterial systematics: a case of Phormidium retzii (Oscillatorailes) using RAPD molecular markers and 16S rDNA Sequence data. - Aquatic Bot 77: 295-309.

[6] Castenholtz, R.W. (1973): Ecology of blue-green algae in hot springs. In: Carr NG, Whitton BA (eds) The biology of blue-green algae. University of California Press, Los Angeles, pp 379-414.

[7] Castenholz, R.W. (1978): The biogeography of hot spring algae through enrichment cultures. - Mitt Int Verein Limnol 21: 296-315.

[8] Castenholz, R.W. (1996): Endemism and biodiversity of thermophilic Cyanobacteria. Nova Hedwigia 112: 33-47.

[9] Castenholz, R.W. (2001): General characteristics of the Cyanobacteria. - In: Boone, D.R., Castenholz, R.W. (Eds.) Bergey's Manual of Systematic Bacteriolgy. Second edition, Volume 1. The Archaea and the Deeply Branching and Phototrophic Bacteria. pp. 474487, Springer, New York.

[10] Cuzman, O.A., Ventura, S., Sili, C., Mascalchi, C., Turchetti, T., D’Acqui, L.P., Tiano, P. (2010): Biodiversity of phototrophic biofilms dwelling on monumental fountains. Microb Ecol 60: 81-95.

[11] Ercolini, D. (2004): PCR-DGGE fingerprinting: novel strategies for detection of microbes in food. - J. Microbiol. Methods 56: 297-314. 
[12] Geitler, L. (1932): Cyanophyceae. In Dr. L. Rabenhorst's Kryptogamen-Flora von Deutschland, Osterreich und der Schweiz, vol. XIV. Akademische Verlag, Leipzig; reprint (1985): Koeltz Scientifi c Books, Koenigstein pp. 1196.

[13] Ghosh, D., Bal, B., Kashyap, V.K., Pal, S. (2003): Molecular phylogenetic exploration of bacterial diversity in a Bakreshwar (India) hot spring and culture of Shewanella-related thermophiles. - Appl Environ Microbiol 69: 4332-4336.

[14] Giovannoni, S.J., DeLong, E.F., Schmidt, T.M., Pace, N.R. (1990): Tangential flow filtration and preliminary phylogenetic analysis of marine picoplankton. - Appl. Environ. Microbiol 56: 2572- 2575.

[15] Gunde-Cimerman, N., Oren, A., Plemenitas, A. (2005): Adaptation to life at high salt concentrations in Archaea, Bacteria, and Eukarya Introduction. - Adaptation to Life at High Salt Concentrations in Archaea, Bacteria, and Eukarya 9: 1-6.

[16] Hongmei, J., Aitchison, J.C, Lacap, D.C., Peerapornpisal, Y., Sompong, U., Pointing, S.B. (2005): Community phylogenetic analysis of moderately thermophilic cyanobacterial mats from China, the Philippines and Thailand. - Extremophiles 9: 325332.

[17] Ionescu, D., Oren, A., Levitan, O., Hindiyeh, M., Malkaw, H., Berman-Frank, I. (2009): The cyanobacterial community of the Zerka Ma'in hot springs, Jordan: morphological and molecular diversity and nitrogen fixation. - Algological Studies 130: 129-144.

[18] Iteman, I., Rippka, R., Tandeau de Marsac, N., Herdman, M. (2002): rDNA analyses of planktonic heterocystous cyanobacteria, including members of the genera Anabaenopsis and Cyanospira. - Microbiology 148: 481-496.

[19] Jing, H., Lacap, D.C., Lau, C.Y., Pointing, S.B. (2006): Community phylogenetic diversity of cyanobacterial mats associated with geothermal springs along a tropical intertidal gradient. - Extremophiles 10: 159-63.

[20] Karina, O.S., Pietrasiak, N., Bohunická, M., Miscoe, L.H., Kovácik, L., Martin, M.P., Johansen, J.R. (2014): Seven new species of Oculatella (Pseudanabaenales, Cyanobacteria): taxonomically recognizing cryptic diversification. - European Journal of Phycology 49(4): 450-470.

[21] Komarek, J., Komarkova, J., Kling, H. (2003): Filamentous Cyanobacteria; in Wehr JD, Sheath RG, eds., - Freshwater Algae of North America: Ecology and Classification, California: Academic Press 117-196.

[22] Kullberg, R.G. (1968): Algal diversity in several thermal springs effluents. - Ecology 49: $751-755$.

[23] Laloui, W., Palinska, K.A., Rippka, R., Partensky, F., Tandeau de Marsac, N., Herdman, M., Iteman, I. (2002): Genotyping of axenic and non-axenic isolates of the genus Prochlorococcus and the OMF-'Synechococcus' clade by size, sequence analysis or RFLP of the internal transcribed spacer of the ribosomal operon. - Microbiology 148: 453-465.

[24] Lemarchand, K., Berthiaume, F., Maynard, C., Harel, J., Payment, P., Bayardelle, P., et al. (2005): Optimization of microbial DNA extraction and purification from raw wastewater samples for downstream pathogen detection by microarrays. - J Microbiol Methods 63:115-26.

[25] Lu, W., Evans, H., McColl, S.M., Saunders, V.A. (1997): Identification of cyanobacteria by polymorphisms of PCR-amplified ribosomal DNA spacer region. - FEMS Microbiol Lett 153: 141-149.

[26] Lyra, C., Hantula, J., Vainio, E., Rapala, J., Rouhiainen, L., Sivonen, K. (1997): Characterization of cyanobacteria by SDS-PAGE of whole-cell proteins and PCR/RFLP of the 16S rRNA gene. - Arch Microbiol 168: 176-184.

[27] Mcgregor, G.B., Rasmussen. J.P. (2008): Cyanobacterial composition of microbial mats from an Australian thermal spring: a polyphasic evaluation. - FEMS Microbiol Ecol 63: $23-35$. 
[28] Miller, S.R, Castenholz, R.W, Pederson, D. (2007): Phylogeography of the thermophilic cyanobacterium Mastigocladus laminosus. - Appl Environ Microb 73: 4751-4759.

[29] Miller, S.R., Castenholz, R.W. (2000): Evolution of thermotolerance in hot spring cyanobacteria of the genus Synechococcus. - Appl Environ Microb 66: 4222-4229.

[30] Moro, I., Rascio, N., La Rocca, N., Di Bella Mi Andreoli, C. (2007): Cyanobacterium aponinum, a new Cyanoprokaryote from the microbial mat of Euganean thermal springs (Padua, Italy). - Algol. Stud 123: 1-15.

[31] Moyer, C.L., Dobbs, F.C., Karl, D.M. (1995): Phylogenetic diversity of the bacterial community from a microbial mat at an active, hydrothermal vent system, Loihi Seamount, Hawaii. - Appl Environ Microbiol 61: 1555-1562.

[32] Muyzer, G. (1999): DGGE/TGGE: a method for identifying genes from natural ecosystems. - Curr Opin Microbiol 2: 317- 422.

[33] Neilan, B.A. (2002): The molecular evolution and DNA profiling of toxic cyanobacteria. - Curr Issues Mol Biol 4: 1-11.

[34] Nikolausz, M., Sipos, R., Revesz, S., Szekely, A., Marialigeti, K. (2005): Observation of bias associated with re-amplification of DNA isolated from denaturing gels. - FEMS Microbiol. Lett. 244: 385-390.

[35] Nollau, P., Wagener, C. (1997): Methods for detection of point mutations: performance and quality assessment. - Clin Chem 43: 1114- 1128.

[36] Nübel, U., Garcia-Pichel, F., Muyzer, G. (1997): PCR primers to amplify 16S rRNA genes from cyanobacteria. - Applied and Environmental Microbiology 63: 3327-3332.

[37] Papke, R.T., Ramsing, N.B., Bateson, M.M., Ward, D.M. (2003): Geographical isolation in hot spring cyanobacteria. - Environ Microbiol 5: 650-659.

[38] Ramsing, N.B., Ferris, M.J., Ward, D.M. (2000): Highly ordered vertical structure of Synechococcus populations within the onemillimeter-thick photic zone of a hot spring cyanobacterial mat. - Appl Environ Microb 66: 1038-1039.

[39] Rayss, T. (1944): Materiaux pour la flore algologique de la Palestine I. Les Cyanophycees. Palestine. - Journal of Botany Jerusalem Series 3: 94-113.

[40] Reysenbach, A.L., Wickham, G.S., Pace, N.R. (1994): Phylogenetic analysis of the hyperthermophilic pink filament community in Octopus Spring, Yellowstone National Park. - Appl. Environ. Microbiol. 60: 2113-2119.

[41] Rippka, R.J., Waterbury, J.B., Stanier, R.Y. (1981): Isolation and purification of cyanobacteria: some general principles. - In: Starr, M.P, Stolp, H, Tru Per, H.G., Balows, A., Schlegel, H.G. (eds.) The prokaryotes, vol. 1. Berlin: Springer, pp. 212-220.

[42] Rocap, G., Distel, D.L., Waterbury, J.B., Chisholm, S.W. (2002): Resolution of Prochlorococcus and Synechococcus ecotypes by using 16S-23S ribosomal DNA internal transcribed spacer sequences. - Appl Environ Microbiol 68: 1180-1191.

[43] Sompong, U., Castenholz, R.W., Anuntalabhochai. S., Peerapornpsial, Y., (2006): Genetical diversity of Mastigocladus in Ranong Hot Spring, Southern Part of Thailand. Chiang Mai J. Sci; 33(3): 363-370.

[44] Sompong, U., Hawkins, P.R., Basley, C., Peerapornpisal, Y. (2005): The distribution of cyanobacteria across physical and chemical gradients in hot springs in northern Thailand. - FEMS Microbiol Ecol 52: 365-376.

[45] Stetter, K.O. (1996): Hyperthermophilic prokaryotes. - FEMS Microbiol. Rev 18:149158.

[46] Tamura, K., Dudley, J., Nei, M., Kumar, S. (2007): MEGA4: Molecular Evolutionary Genetics Analysis (MEGA) software version 4.0. - Molecular Biology and Evolution 24: 1596-1599.

[47] Taton, A., Grubisic, S., Balhasart, P., Hodgson, D.A., Laybourn-Parry, J., Wilmotte, A. (2006): Biogeographical distribution and ecological ranges of benthic cyanobacteria in East Antarctic lakes. - FEMS Microbiol Ecol 57: 272-289.

[48] Taton, A., Grubisic, S., Brambilla, E., De Wit, R., Wilmotte, A. (2003): Cyanobacterial diversity in natural and artificial microbial mats of Lake Fryxell (McMurdo Dry Valleys, 
Antarctica): a morphological and molecular approach. - Appl. Environ. Microbiol 69: 5157-5169.

[49] Ward, D.M, Ferris, M.J, Nold, S.C, Bateson, M.M. (1998): A natural view of microbial biodiversity within hot spring cyanobacterial mat communities. - Microbiol Mol Biol Rev 62: 1353-1370.

[50] Ward, D.M., Castenholz, R.W. (2000): Cyanobacteria in geothermal habitats. In Whitton BA, Potts M (Eds) The ecology of cyanobacteria. Their diversity in time and space. Kluwer Academic Publishers, Dordrecht, 37-59.

[51] Ward, D.M., Weller, D., Bateson, M.M. (1990): 16S rRNA sequences reveal uncultured inhabitants of a well-studied thermal community. - FEMS Microbiol Rev 75: 105-116.

[52] Weller, R., Batterson, M.M., Heimbuch, B.K., Kopczynski, E.D., Ward, D.M. (1992): Uncultivated cyanobacteria, Chloroflexus-like and spirochete-like inhabitants of a hot spring microbial mat. - Appl Environ Microbiol 58: 3964-3969.

[53] West, N.J., Adams, D.G. (1997): Phenotypic and genotypic comparison of symbiotic and free-living cyanobacteria from a single field site. - Appl Environ Microbiol 63: 44794484.

[54] Whitton, B.A., Potts, M. (2000): The ecology of cyanobacteria. Their diversity in time and space. - Springer, Berlin., p. 669.

[55] Wilmotte, A., Demonceau, C., Goffart, A., Hecq, J.H., Demoulin, V., Crossley, A.C. (2002): Molecular and pigment studies of the picophytoplankton in a region of the Southern Ocean (428-548 S, 1418-1448 E) in March 1998. - Deep-Sea Res., Part 2, Top. Stud. Oceanogr. 49: 3351-3363.

[56] Wright, E.S., et al. (2012): DECIPHER, A Search-Based Approach to Chimera Identification for 16S rRNA Sequences. - Applied and Environmental Microbiology 78(3):715-25. 